Jasztrab Péter János ${ }^{1}$ - Csőke Gergely ${ }^{2}$

\title{
Építőipari kivitelezések tűzvédelmi szabályozásának vizsgálata
}

\section{An Examination of Fire Safety Regulation in Construction Sites}

A szerzők az építőipari kivitelezések során adódó tüzbiztonsági kérdésekkel kívánnak foglalkozni ebben a cikkben, és a hazai egyes ismert, médiában megjelent esetek és saját gyakorlati tapasztalataik alapján járják körbe a témakört, hogy egy általános esetleirás után összevessék a hazai jogi elöirásokat egyes nyugat-európai szabályozásokkal. Céljuk, hogy felhívják a figyelmet a területen tapasztalható nehézségekre és egy gondolatébresztő irást készitsenek. Mindezzel rá kivánnak világítani a jelen lévő kockázatokra és a tudatos megelőzés fontosságára, valamint a jogszabályalkotóifelelősségre, amely változások implementálása a gondosság szerepének megerősitését eredményezheti az épitőipari kivitelezések alatt.

Kulcsszavak: épülettüz, tüzmegelőzés, tüzvédelmi szabályozás

In this article the authors intended to focus on fire protection during construction of buildings, and to discuss fire-related issues and studies from the perspective of their practical experience, furthermore, to discuss cases published in media reports. They compare the domestic legal requirements with pieces of Western European legislation, whereby their goal is to provide a general, thought-provoking description, thus highlighting the presence of risks and the need for prevention, raising awareness for the urgency of changes and the responsibility of the legislation, and finally, strengthening carefulness, which may result in greater safety during the constructions.

Keywords: fires in buildings, fire prevention, fire safety regulations

PPG Trilak Kft., EHS vezető, villamos mérnök, gépészmérnök, e-mail: jasztrabp@yahoo.com, ORCID: https:// orcid.org/0000-0002-4162-427X

2 Egyéni vállalkozó, tűzvédelmi tervező szakmérnök, e-mail: csoke.gergely@hanoplan.hu, ORCID: https://orcid. org/0000-0001-9521-7103 


\section{Bevezetés}

Általánosan elmondható, hogy a magyar lakosság legnagyobb értékű vagyontárgya az ingatlana, ${ }^{3}$ ezért az abban történt, bármilyen mértékü kár érzékenyen érint bennünket. $A$ bekövetkezett tragédia utólagos elemzése csak kevés esetben szolgálja a hasznos tapasztalatok elterjedését, közzétételét, amely egymagában is hangsúlyozza a tüzbiztonság kérdésével való foglalkozás szükségességét.

Napjainkban előtérbe kerültek a beruházási, átalakítási munkálatok, hála a lakásteremtő, korszerüsítő gazdasági dotációknak és ingatlanpiaci változásoknak, amelyek ezt a pozitív tendenciát erősítik. Ha azonban visszatekintünk a közelmúlt alakulásaira, nem szabad megfeledkeznünk a megelőző korok tapasztalatairól sem, ezért tudatos és követhető követelmények szerint kell meghatározni azon peremfeltételeket, amelyekkel megelőzhető a veszélyhelyzetek kialakulása, és megteremthető az építőipari kivitelezések időszakára a tűzbiztonság. Nem egy olyan példa hozható, ${ }^{4}$ legyen az csak állagmegőrző felújítás, hőszigetelés-korszerüsítés vagy más beruházás, ahol a projektek alatt vagy azok közötti „szünetben" tűz keletkezett és a szerkezetek megsérültek. Köztudott, hogy az építkezések pénzügyi konstrukciójuktól, a beruházók finanszírozási helyzetétől erősen függenek, aminek következtében a kivitelezések gyakran elhúzódhatnak, vagy hosszan szünetelhetnek. ${ }^{5}$ Ráadásul az építésügyi törvény engedélyezési eljárásaiban történt változások is befolyással vannak a kialakult viszonyokra. Így jogosan merülhet fel a tüzvédelmi szakemberek részéről, hogy van-e olyan tudatosság a tulajdonosi és a kivitelezői vagy akár a tervezői oldalról, amely garantálja a biztonságot. Létezik-e a végrehajtásra megfelelő felügyelet, illetve a megelőzés milyen módon biztosított? ${ }^{6} \mathrm{Az}$ építkezés jogi alanyai ${ }^{7}$ mennyire foglalkoznak például a kockázati osztállyal, tűzoltó készülékekkel, az oltóvízzel vagy egyéb tűzvédelmi igénnyel, valamint annak ellenőrzésével. Követik-e az átalakítások, módosítások módja miatt az épületszerkezetekben bekövetkező jellemzők és az őket érintő tűzbiztonsági követelmények változásait. ${ }^{8}$

2016. május óta a hatályos kormányrendelet a tervező és kivitelező felelősségi körét növelte, aminek következtében a részt vevő felek szerződésben kell, hogy a biztonságról való felelősséget és gondosságot rögzítsék. Legyen az akár a lehetséges kockázatok felmérése, tűztávolság betartása, oltóvíz, menekülési feltételek teljesülése, vagy akár a beépítendő építési termékek, szerkezetek tűzállósági teljesítményeinek jellemzői. Ennek ellenére számtalan hiányosság tapasztalható, ezért a cikk az ilyen jellegü problémákkal kíván foglalkozni. A következőkben tekintsünk át pár esetet, és ezt követően kitérünk a jogszabályi előírásokra, statisztikákra is.

3 Hasonlóan elfogadhatatlan, ha létfontosságú rendszerekben vagy kulturális örökségben következik be kár, de itt elsősorban az építőipari kivitelezések közösségi érdekvédelmi mint a „lakáscélú ingatlanállomány” védelmének egyik módjáról lesz szó.

4 Az egyik legutolsó és mindenki által ismert eset a Notre-Dame-székesegyház leégése.

5 Elég, ha a MH Egészségügyi Központ Papp Károly utcai épületegyüttesének 1980-as években indult és a több mint 10 évre leálló építkezésre gondolunk (lásd az 1. ábrát). JÁMBOR 2019; KÁLMÁNFI 2007.

6 Itt értsd a 456/2015. (XII. 29.) Korm. rendelet változásait. Az erről szóló részletes cikk hivatkozását lásd az irodalomjegyzékben. Koós 2016.

7 Itt értsd a tervezőt és a felelős kivitelezőt, építtetőt vagy annak megbízottját.

8 JÁMBOR-KOÓs 2015; JÁMBOR 2019. 

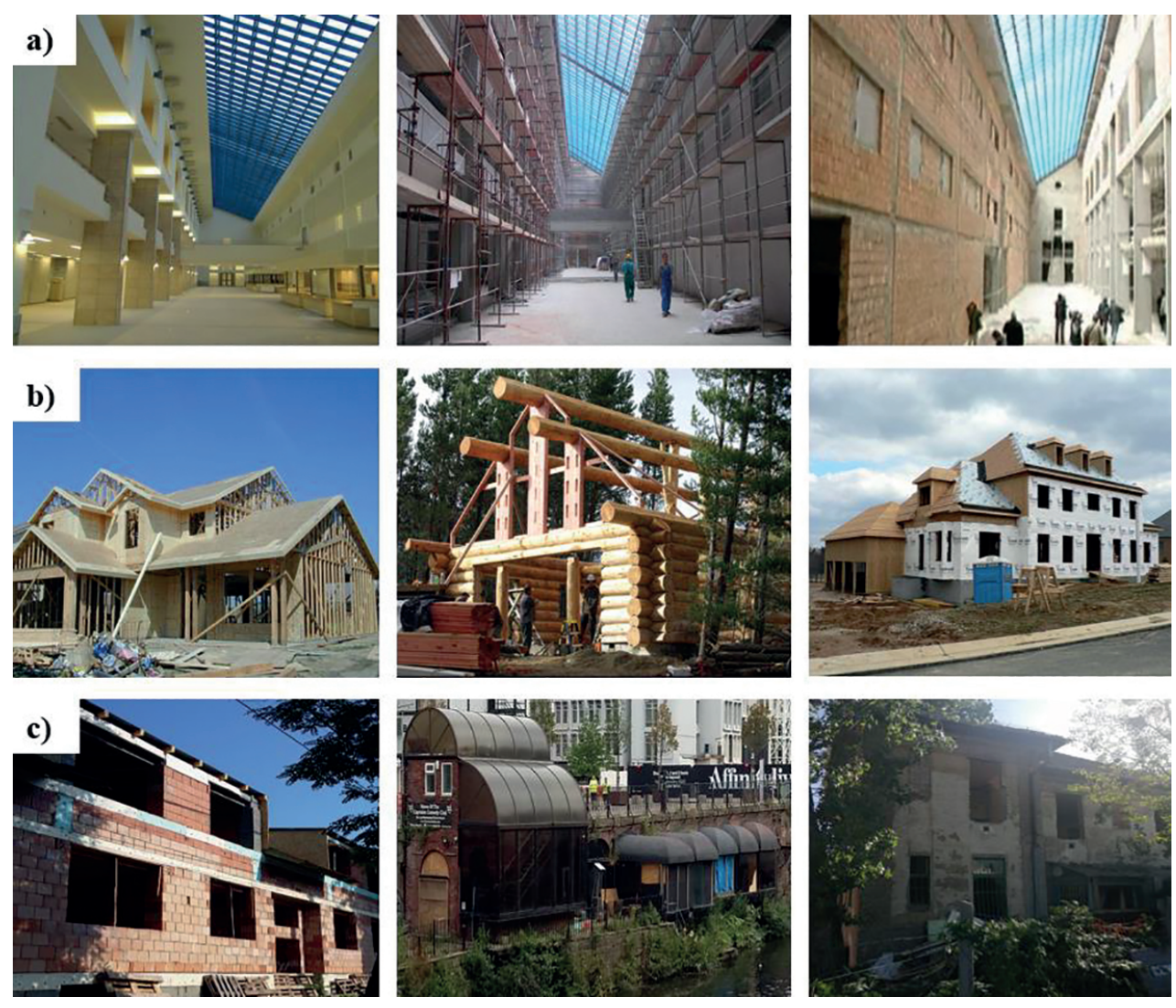

1. ábra. Képek kivitelezésekröl ${ }^{9}$

Forrás: a szerzők szerkesztése R. Bakonyi 2004, Szatmári 2008, Tarpataki 2018 alapján

\section{Túzesetek és lehetséges okaik}

A teljesség igénye nélkül a következőkben röviden bemutatjuk az elmúlt évek ellenörzései során szerzett tapasztalatokat, illetve a médiában fellelhető esetek vizsgálatából levonható tanulságokat, amelyek segítenek képet alkotni számunkra a kivitelezés során kialakuló veszélyeztetettségröl.

9 Az 1. ábra képei (a)-(c): (a) Honvédkórház építéseinek fázisairól és az építkezés szünete alatti állapotról R. BAKONYI 2004; SZATMÁRI 2008, (b) könnyűszerkezetű házak kivitelezések alatt TARPATAKI 2018 és (c) szüneteltett kivitelezések képe. 
Engedjék meg ennek érdekében, hogy a cikkünk tárgyát egészen a „kályhától indulva," a korábbi híradásokból már jól ismert, a szívünknek nagyon kedves, de sajnos nemcsak anyagi, de esztétikai kárt szenvedett épülettel, a nem is olyan régen, tűzeset következtében leégett Kodály köröndi palotával ${ }^{10}$ kezdjük, amelynek esete „orvosi lóként” is szolgál számunkra (lásd 2. ábra).

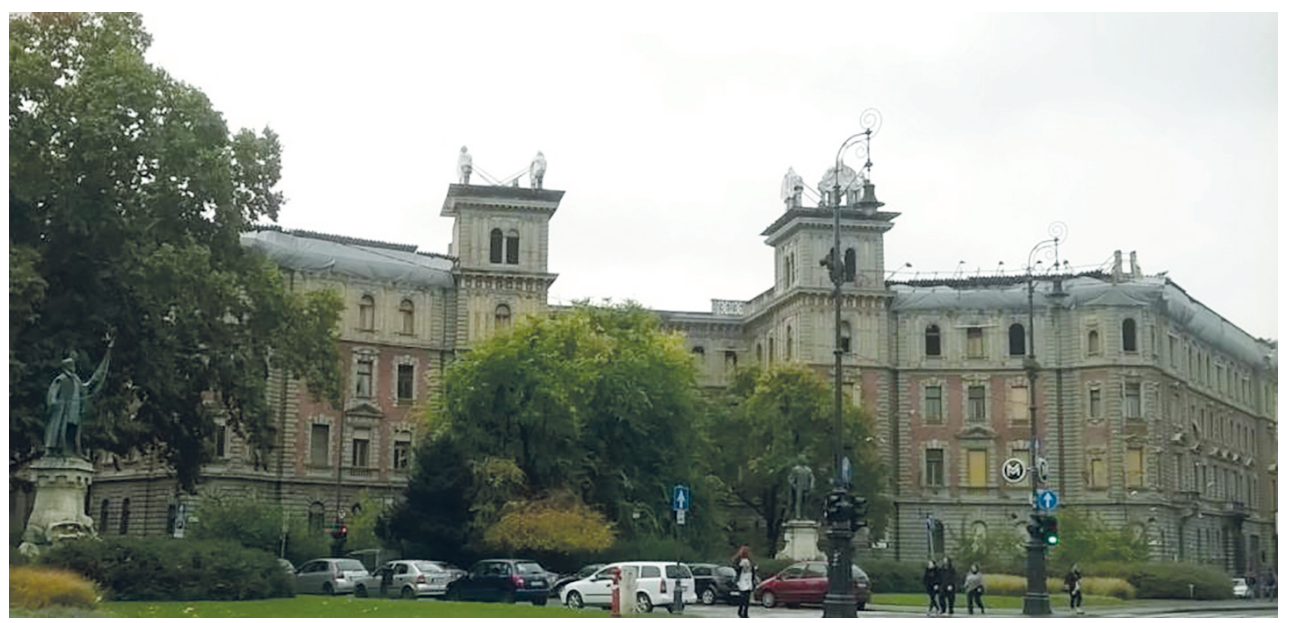

2. ábra. A budapesti Andrássy úton volt látható a leégett Kodály köröndi palota szomorú látképe

Forrás: a szerzők felvétele

A beruházás során a kivitelező a tetőszerkezetet és a felső szintet, illetve a helyiségek közötti tűzállósági teljesítménnyel rendelkező szerkezeteket elbontotta. Ezt a „hatóságok nem kifogásolták”, ezért a hírekben „megfelelő tűzvédelmi körülményekkel rendelkezettnek titulálták."11 A megrendelő az elhúzódó munkálatokból adódó beázást megakadályozó célzatú szigetelést nem tartotta „építőipari munkálatnak". ${ }^{12}$ A nyílt lánggal járó tevékenység végrehajtásakor egy láda homok szolgált a tűz megfékezésére, amelyet az ott-tartózkodók már csak későn érzékeltek. Lángra kapott az épület, és a hiányos (normális esetben a tűzbiztonságot szolgáló) elemek nem voltak képesek a tüzet megfékezni. A hatalmas lángok akadály nélkül, "felfoghatatlanul" gyorsan terjedtek tovább. A tetőszerkezet „teljes terjedelmében égett”, aminek következtében az épület „életveszélyessé vált". ${ }^{13}$

102014 nyarán gyulladt ki. MTI 2014a.

11 SZABÓ 2015.

12 http://magyartarsashaz.hu/2015/01/18/andrassy-uti-tuz-ezt-allapitotta-meg-a-tuzvizsgalat/ (A letöltés dátuma: 2019. 08. 01.)

13 MTI 2014a; SzABÓ 2015; http://magyartarsashaz.hu/2015/01/18/andrassy-uti-tuz-ezt-allapitotta-meg-a-tuzvizsgalat/ (A letöltés dátuma: 2019. 08. 01.); MTI 2014b; KISS 2015. 


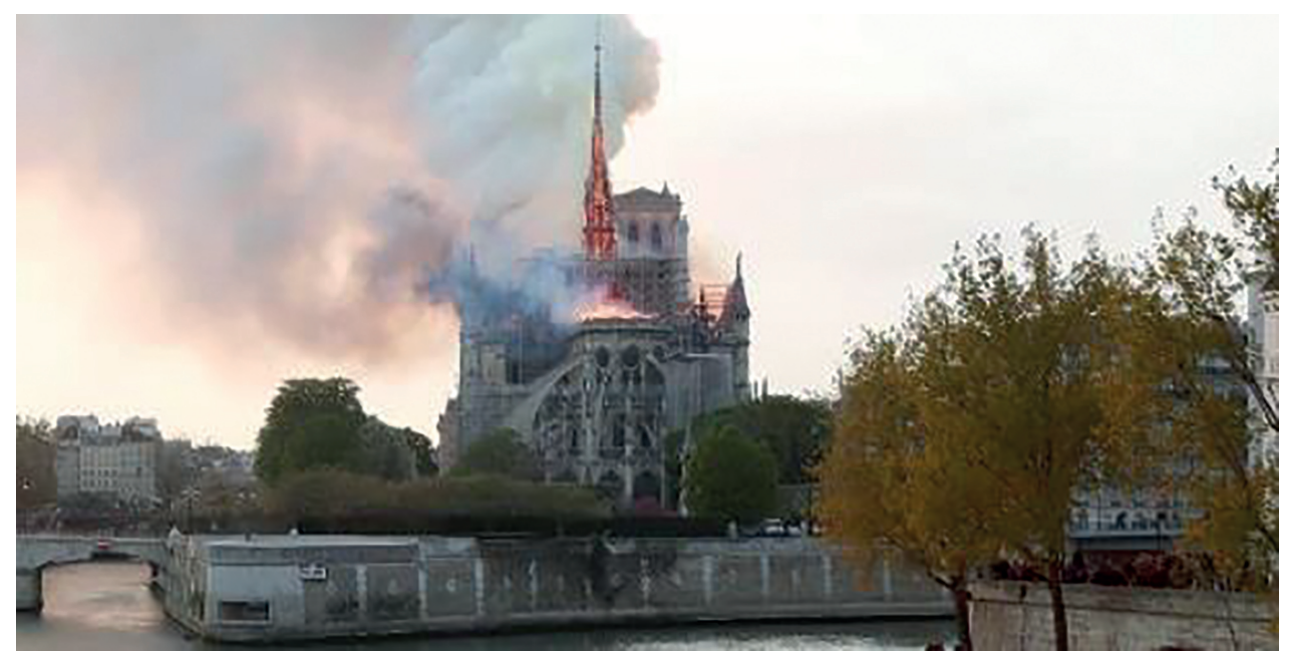

3. ábra. Az égő párizsi Notre Dame-székesegyház

Sajnos kihagyhatatlan a példáink közül a párizsi Notre Dame tűzesete, ahol a restaurálási munkálatokhoz felállított állványzaton, a tetőszerkezetnél csaptak fel a lángok (3. ábra). Kialakulásához az illetékesek nyilatkozatai alapján munkahelyi gondatlanság vezetett, és az egész nemzet gyászolt. ${ }^{14}$

De előfordul, hogy emberi jelenlét nélkül is keletkezik tüz. Ez történt Besztercén, amikor renoválás során egy villámcsapás miatt gyulladt ki és égett le a templomi magastető. Továbbá az építkezési esetek sorában említeni lehetne a Horváth Mihály téren lévő volt telefonközpontot, a Margit hidat vagy a hévízi húszlakásos tüzet, de a darányi óvodát vagy a majsai lakóházat is, amelyből akár néhány is már soknak számít, értve ezalatt az egyén vagy a nemzet nagymértékü anyagi és negatív erkölcsi vonzatait (lásd a 4. ábrát). ${ }^{15}$

14 Nem elszigetelt esetről beszélünk Párizs történetében. 2016-ban a híres Ritz Hotel gyulladt ki a renoválási munkák alatt. Reuters 2016.

15 PAP 2008; https://rtl.hu/rtlklub/hirek/belfold/cikkek/2010/08/29/tuz_a_margit_hidon (A letöltés dátuma: 2019. 08. 01.); https://jozsefvaros.hu/hir/2804/a-szellozorendszer-szigetelese-kapott-langra (A letöltés dátuma: 2019. 08. 01.); JUHÁSZ 2015; www.sonline.hu/somogy/kek-hirek-bulvar-somogy/gazrobbanas-a-daranyi-ovodaban-ket-sulyos-serult-527187/ (A letöltés dátuma: 2019. 08. 01.); Reuters 2016, MTI 2015. 

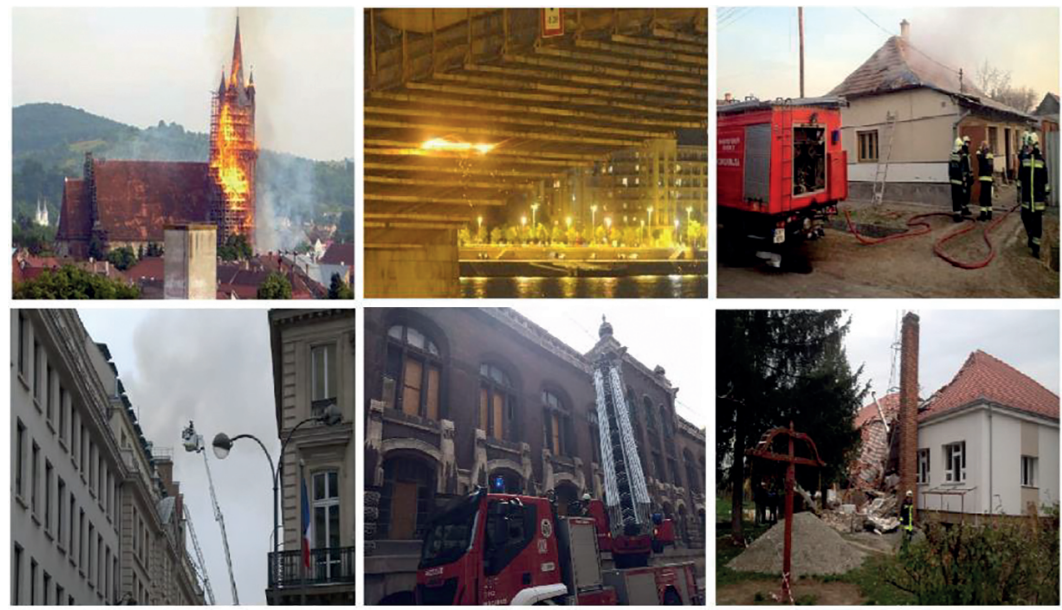

4. ábra. Építkezésekkel összefüggő tűzesetek (Bal felső képtől óramutató járásának irányába haladva: besztercei, Margit hídi, darányi, majsai, józsefvárosi, párizsi Ritz Hotel-i tủzeset)

Forrás: a szerzők szerkesztése Pap 2008, https://rtl.hu/rtlklub/hirek/belfold/cikkek/2010/08/29/tuz_a_margit_hidon (A letöltés dátuma: 2019. 08. 01.), https://jozsefvaros.hu/hir/2804/a-szellozorendszer-szigetelese-kapottlangra (A letöltés dátuma: 2019. 08. 01.), JUHÁsz 2015, https://www.sonline.hu/somogy/kek-hirek-bulvar-somogy/gazrobbanas-a-daranyi-ovodaban-ket-sulyos-serult-527187/ (A letöltés dátuma: 2019. 08. 01.), Reuters 2016, R. BAKONYI 2004, MTI 2015 alapján

A médiában meg nem jelent, kevésbé ismert szituációkat vizsgálva, a tűz keletkezésének okától függetlenül megállapítható, hogy a kivitelezések során az épített szerkezetek sérülékenyek, és a kockázatot növelik a felvonuló építőipari vállalatok munkálatai. Jellemző rájuk, hogy a tevékenységek gyakran párhuzamosan kezdődnek és a dolgozók a helyi viszonyokról kielégítő ismeretekkel ritkán rendelkeznek. Ilyenkor a meglévő passzív és aktív tűzvédő rendszerek nem teljesen képesek a kezdetleges vagy félkész állapotuk miatt teljesítményüket garantálni. Az építménybe nincsenek szervesen beépülve, integrálva és nem illeszkednek az épület szerkezeteibe. Az épületszerkezetek tűzállósága alacsony, és nem nyújtanak hatékony védelmet a keletkezett tűz ellen. Ideiglenes jellegükből adódóan fokozott figyelmet igényelnek, és elengedhetetlen a megfelelő biztonsági szintet nyújtó műszaki vagy azt pótló intézkedés bevezetése. Az ellenörzésünk során tapasztalt esetekből szemezgetve gyakran található a burkolatok folytonos, illetve megfelelő felületi kialakításának hiánya, tűzvédőképesség figyelmen kívül hagyása, fedetlen beton és fémtartó szerkezetek, meggyengített boltozatok, valamint válaszfal tömör téglafalának helyettesítése farostlemezzel. Számtalanszor előfordul tüzállóságot növelő burkolatok, festékek eltávolítása is (lásd az 5. ábrát). 

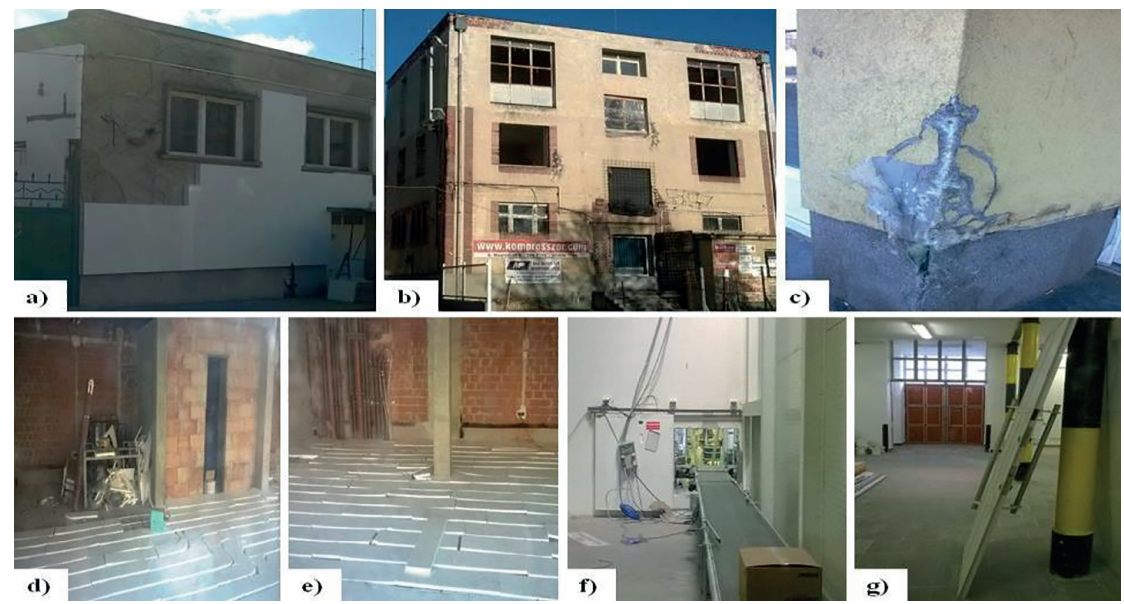

5. ábra. Kivitelezés során az épület tüzbiztonságát érintő csökkentő tényezők ${ }^{16}$

Forrás: a szerzők felvételei

Komoly veszélyt jelent a tűzszakaszolások megbontása, a tűzszakaszhatáron átvezető elektromos kábelek és a technológiai csővezetékek, a kábelcsatornák nem előírásszerű használata, valamint a szellőző- és levegő-utánpótló berendezések vezérlésének kiiktatása. Az építmények ilyen állapotában a kábelátvezetések tűzgátló lezárása, és a tűz terjedését gátló hő hatására duzzadó, falba építhető elemek, mint például a mandzsetta, egyes esetekben még a dilatációs hézagok rugalmas tüzvédő tömítései is gyakran hiányoznak. Köztudott, hogy a védelem nélküli acél teherhordó-szerkezetek (acélpillérek, oszlopok, gerendák és áthidalók) vonatkozó tűzállósági teljesítménye alacsonyabb szintű. Sürűn lehet találni olyan építőipari munkálatot, ahol a menekülési útvonalakon elhelyezett tűzgátló nyílászárók nincsenek, az álmennyezetek, membránok részlegesek. A szintek között a födémek hiányosak és átjárhatók. A menekítésben és a kárenyhítésben a beavatkozók közlekedése korlátozott vagy akadályozott a felhasználódó anyagok vagy hulladékok miatt. Nem egyszer fordul elő kivitelezés során, hogy a válaszfalak, tűzgátló üvegek integritását ideiglenesen megszüntették. A szellőző- és kábelcsatornák, menekülési utak nem rendeltetésszerü használata következik be vagy annak teljes eliminálása történik meg (lásd a 6. ábrát).

16 Az 5. ábra (a)-(g) képei: (a) nem megfelelő szigetelési rétegrend és rögzítés, szabadon maradt, védetlen utcafronton expandált polisztirolhab, (b) homlokzati tűzterjedési gát, tűzgátló elem, távolság nélküli nyílászárók, (c) lábazatnál megbomlott rétegrend, (d) éghető padlón felhalmozott éghető anyagok és feszültség alatt lévő sérült elektromos berendezés, (e) padlófütés részeként lerakott éghető szigetelés, bontott elektromoskábel-vezetékek mellett, (f) működő szállítószalag mellett kiiktatott, kiékelt tűzgátló ajtó, lógó nagyfeszültségű vezetékkel,

(g) vissza nem helyezett, be nem épített vagy átalakított tűzgátló ajtók. 

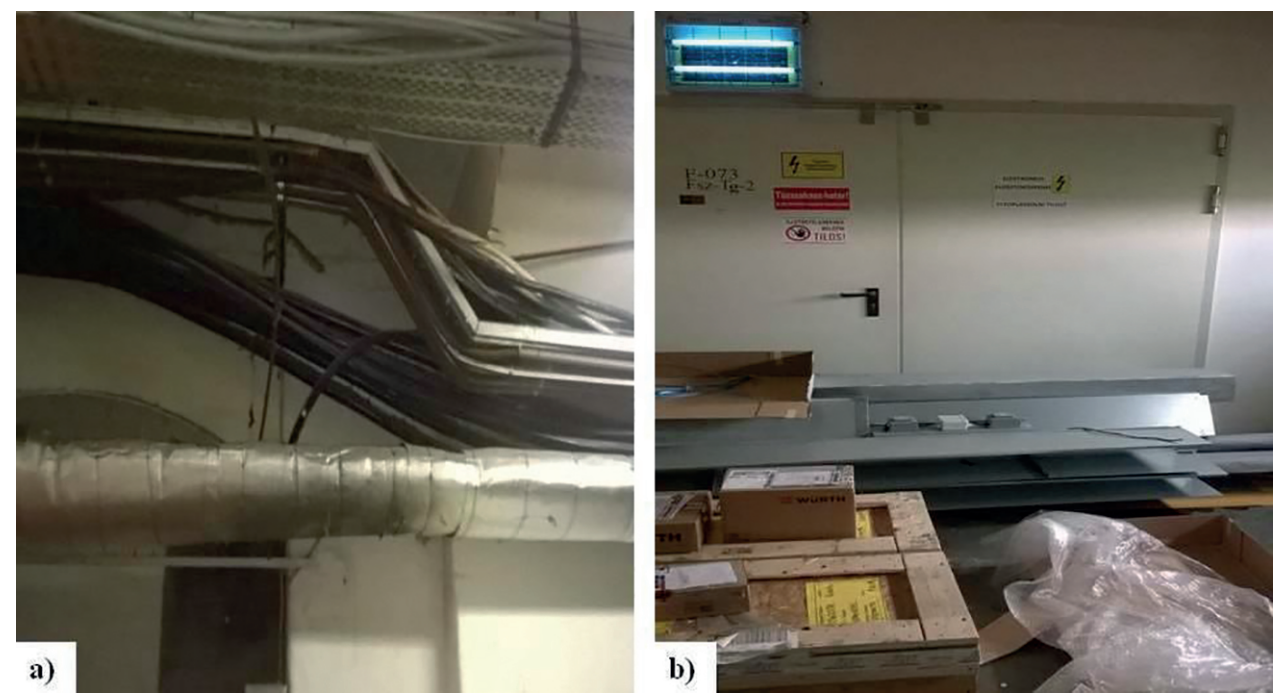

6. ábra. Kivitelezés során a tűzbiztonságot gyakran csökkentő tényezők: (a) túlzsúfolt kábeltálcák, kötegek, ${ }^{17}$

(b) eltorlaszolt helyiségek. ${ }^{18}$

Forrás: a szerzők felvételei

Nem ritkán az építőipari munkálatok során az aktív védelmeket szintén kiiktatják. Hasonló problémák néha már építőipari kivitelezés előtt vagy után is felmerülnek. Mivel előfordulhat, hogy ezek a vagyonvédelmi rendszerekbe integráltak, és az abban történt bármi változás kihatással volt a tűzbiztonságra is, amelyről tájékoztatás nem történik, ezért az eszköz inaktivitása teljesen észrevétlen marad. Az aktív védelem egyik fontos eleme a tűzjelző rendszer. Feladata a jelzés esetén a szellőztetők, légkezelők, füstelvezetők, tűzszakasz-nyílászárók, beépített oltórendszerek vezérlése, elektromos vezérlésű ajtók nyitása, vészvilágítás bekapcsolása, tűzoltók értesítése. A jelen lévő éghető anyagok potenciálisan növelik a kockázatot, mivel az energiának és a kitettségének függvényében készen állnak az égéshez szükséges feltételek.

Tapasztalatunk szerint a leggyakrabban előforduló veszélyforrások:

- éghető anyagokat huzamosabb ideig tároló helyek,

- építési, bontási hulladékok, törmelékek,

- ideiglenesen beépített segédanyagok, építmények, szerkezetek,

- nyomástartó edények,

17 Termográfiás vizsgálat igazolta vissza a kábelek melegedését.

18 Az ábrán a tűzvédelem szempontjából fontos kapcsolóhelyiség. Ebben az esetben csak emelőszerkezettel volt lehetséges a felhalmozott anyagok mozgatása. 
- fütési rendszerek, tüzhelyek,

- gáz-, elektromos vezetékek, berendezések, készülékek, szerkezetek,

- próbaüzem alatt lévő és ideiglenes üzemi berendezések,

- egyéni szokások, mint a dohányzás.

Irodalomban nem megfelelő kivitelezési hibáknak titulálják:19

- a nem megfelelő építési termék beépítését (építési terméknek nem minősülő anyag alkalmazása),

- egyes munkanemek felügyelet nélkül hagyását,

- idegenek bejutását a területre,

- építési termékek szakszerütlen összeépítését,

- elemkészlettől idegen anyag, komponens használatát,

- nem hozzáférhető helyen befejezetlen munkákat - mint álmennyezeti terek (hiányzó tüzgátló tömítések),

- nem igazolt teljesítményű építési termék alkalmazását,

- nem az elkészült szerkezetre vonatkozó megfelelőségi igazolás kiállítását.

A jól ismert veszélyek ellenére a mindenre kiterjedő kontroll ritkán valósul meg, föleg a felújítási, kivitelezési munkálatok során. Fontos hangsúlyozni, hogy érdekérvényesítő szerepe elsősorban az érdekelt feleknek van. Sajnos a tapasztalatok azt mutatják, sok esetben a kellő jártasság vagy ismeretek hiányában még lehetőség sincs a preventív eljárások maradéktalan betartatására.

\section{Statisztika}

2011 óta a KSH nyilvántartása és a CTIF ${ }^{20}$ statisztikája szerint csökkenő tendenciát mutatva, éves szinten körülbelül 20 ezer tűzeset van Magyarországon, ${ }^{21}$ amiböl iparban és építőiparban együtt összesen közel 500. A lakóingatlanokban 6-7 ezerben keletkezik kár évröl-évre. Ezek közül 2018-ban 15328 regisztrált beavatkozást igénylő tűzesetből 106 keletkezett építkezési területen. Magyarországon a kereskedelmi és szolgáltató helyiségekben ez a szám 216, illetve az ipari termelési létesítményekben 326 darab volt, amely nem elenyésző szám. ${ }^{22}$

19 TAKÁCS 2012

20 Comité Technique International de prevention et d'extinction de Feu, azaz Tűzoltóságok és Mentést Végző Szervezetek Nemzetközi Szövetsége.

21 A CTIF 2016-os jelentése alapján kb. 63320 bevetése volt a katasztrófavédelemnek. BRUSHLINSKY et al. 2018.

22 www.langlovagok.hu/361/tuzesetek-szama-es-helye-magyarorszagon-2006-2016-ig/ (A letöltés dátuma: 2019. 08. 01.); https://mabisz.hu/nyolc-ev-alatt-negyvenmilliardot-fizettek-ki-a-biztositok-tuzkarokra/ (A letöltés dátuma: 2019. 08. 01.); BRUSHLINSKY et al. 2019. 


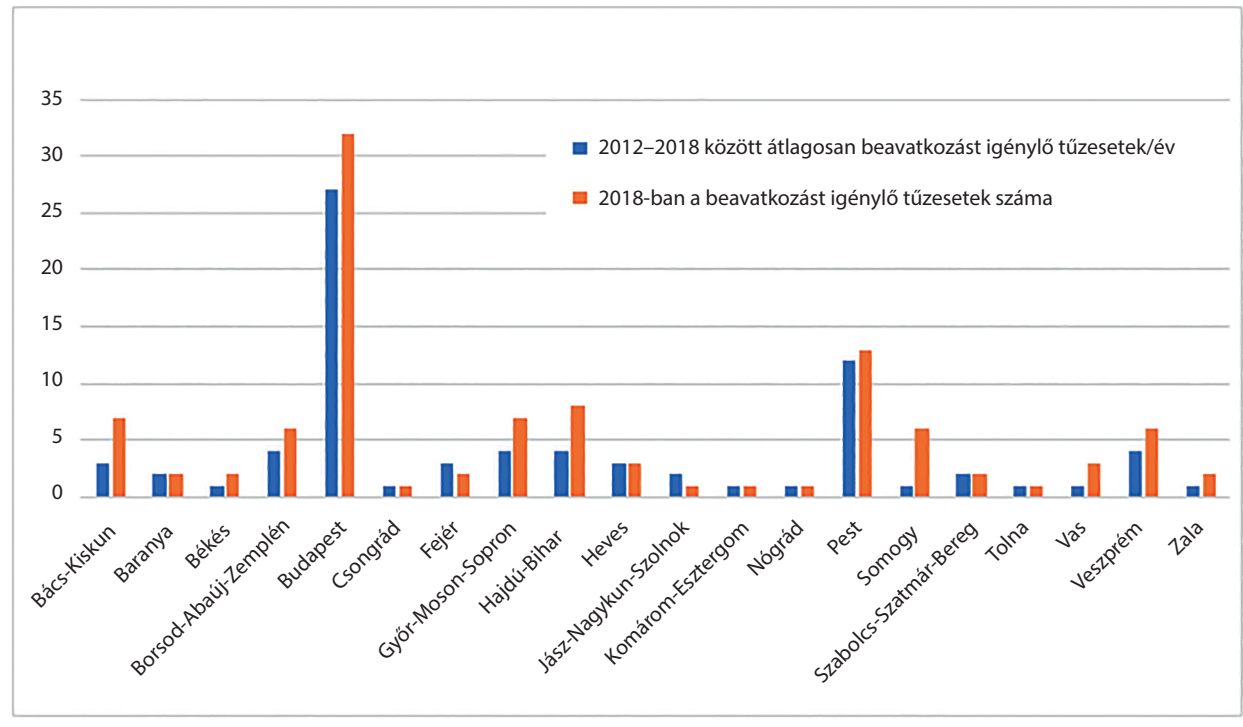

7. ábra. Építkezési területen beavatkozást igénylő tűzesetek évenkénti száma Magyarországon 2012-2018 között, megyei bontásban

Forrás: a szerzők szerkesztése

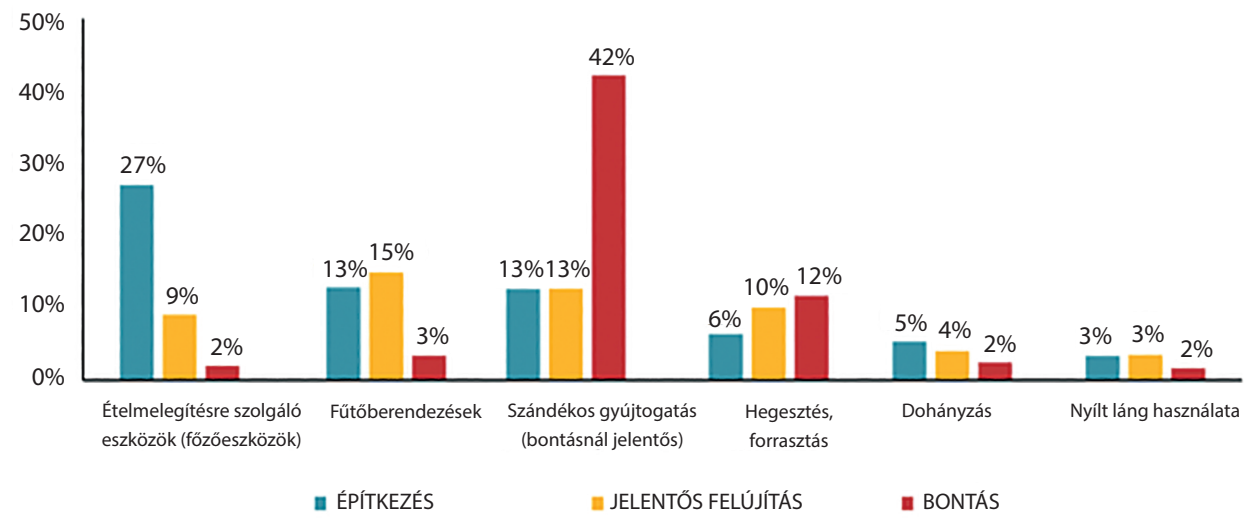

8. ábra. Tüzesetek 2010-2014 között átlagos évi százalékos építés, felújítás, bontás alatt lévő épületekben (USA, NFPA) 
Rontja a statisztikát, hogy az 1996. évi XXXI. törvény szerint a tüzesetet vagy annak „közvetlen veszélyét" jelenteni kell, ${ }^{23}$ de a 39/2011. (XI. 15.) BM rendelet értelmében a tüzoltók, ha a tüzeset és a bejelentés között nem telt el 2 óra, tüzvizsgálati cselekményre intézkedni kötelesek, azonban a tüzoltói beavatkozás nélkül eloltott vagy beavatkozás nélkül elaludt tüzekre bejelentési kötelezettség nincs, de ha létezik is statisztika, ezzel nem kivánunk foglalkozni ebben a cikkben.

Az Amerikai Egyesült Államokban a tűzesetek jól nyilvántartottak. Az NFPA (Nemzeti Tüzvédelmi Szövetség) 2017-es kutatása szerint 2011-2014 között éves átlagban 8440 építkezési tüzeset volt az országban. 13 halálesetet, több mint 100 polgári sérülést és legalább 300 millió dollár közvetlen vagyoni károkat okoztak. A statisztika azt mutatja, hogy az esetek többségében ebből az ideiglenes tủzgyújtási tevékenységből vagy fütőberendezések nem körültekintő üzemeltetéséből eredt (8. ábra). ${ }^{24}$

Az Amerikai Egyesült Államokban közel hét nagy építkezést rombolt le a tűz 2017-ben. Bostontól közel 10 mérföldre 260 lakásos komplexum égett porig, a kárt közel 110 millió dollárra becsülik. Kolorádóban 118 éves malom vált a tűz martalékává, illetve a Vermont Egyetemen zajló épületfelújítás gyulladt ki, ahol az elmondás szerint a hétszintes épület „akkora tüzet okozott, hogy az időjárási müholdak is észlelték." ${ }^{25}$

A teljesség kedvéért meg kell említeni, hogy az USA-ban a faszerkezet használata virágzik a többcsaládos lakóépületek esetében az ország egyes területein. Az amerikai népszámlálási iroda adatai azt mutatják, hogy ebben a kategóriájában már évek óta messze ezek a legnépszerübb épületek. 2016-ban az Egyesült Államokban épült többcsaládos épületek 84\%-át favázas szerkezetek alkották. Ez az arány az elmúlt évek során nem változott. A helyi szakemberek szerint, az építés alatt álló acélépületben fellépő tűz veszélye megegyezik az építés alatt álló favázas épületben fellépő tűz kockázatával (9. ábra). ${ }^{26}$

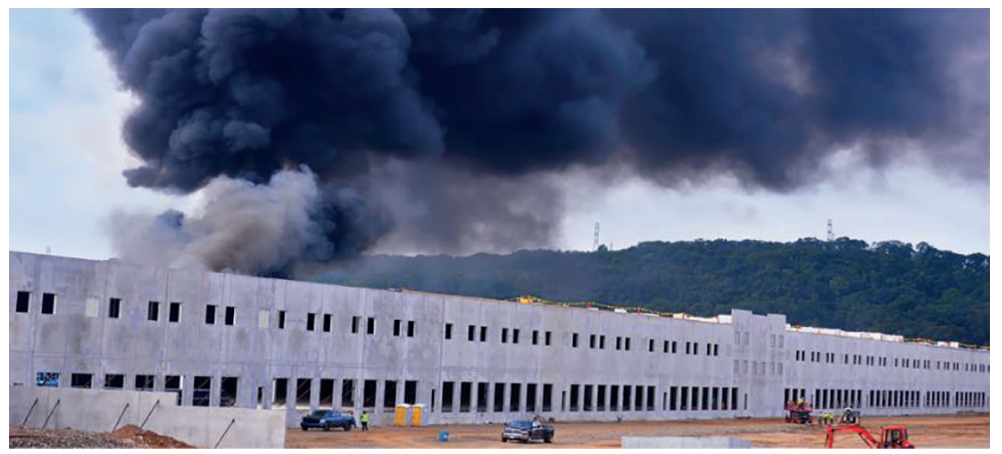

9. ábra. Egyenlő esélyek ${ }^{27}$ (Ch Shipley)

3 1996. évi XXXI. törvény.

4 VERZONI 2017.

25 VERZONI 2017.

26 VERZONI 2017.

27 A tüz megrongálta a pennsylvaniai Betlehemben épülő nem könnyűszerkezetes raktárt. 
A szomszédos Ausztriában szintén sok kárt okoztak már az építkezési és az átalakítási munkálatok alatt keletkezett tűzesetek. 2009-ben Linzbe flexelés miatt, 2012-ben pedig Leopoldstadtba, a Wirtschaftsuniversitätre ${ }^{28}$ (egyetemre) vonultak ki a tűzoltók. Korábban a bécsi Sofiensäle szerkezete súlyosan károsodott a felcsapó lángoktól, amelyet a kiérkező egységek nem tudtak már megfékezni, és a tető beszakadt. A tragédia okozói a tetőtéri munkálatok voltak, ahogy 2019 nyarán is, mikor Tirolban egy épülő szálloda gyulladt ki. Valamint a bécsi Dunacentrumban történt tűzeset hátterében is a régóta zajló építkezést feltételezik. ${ }^{29}$

A brit statisztikai hivatal korábbi adatai alapján 2009-2010 között a faszerkezetek és más épületek összehasonlításában a faszerkezeteknél sokkal nagyobb a tüzesetek száma. 2009-től egészen 2012-ig több mint 1000 esetet regisztráltak az Egyesült Királyságban. ${ }^{30}$

Az Európai Unió már 2003-ban kampányt kezdeményezett az építőmunka biztonságáért, és az Európai Tanács bejelentette a tűzmegelőzési kezdeményezést, amelynek célja az információcsere elősegítése. Az első plenáris ülését 2019 februárjában tartotta meg. ${ }^{31}$

A cél, hogy a különböző adatok gyűjtését egységesítsék a témában. Jelenleg nincsen kielégítő nemzeti statisztika összehasonlításához keretrendszer. Kialakításával könnyebben megállapíthatók lesznek a jellemző trendek. ${ }^{32}$

\section{Szabályozás}

\section{Hazai viszonyok}

Az építőipari kivitelezések során betartandó tűzvédelmi előírások céljai egyértelműen a tüzek megelőzése, segítségnyújtás, jogok és kötelezettségek megállapítása. Az állam feladata a biztosítandó feltételek egyértelmű meghatározása, szabályozása, ezért a következőkben az építkezéshez, felújításhoz, átalakításhoz, bontáshoz tartozó tűzmegelőzési előírásokra ${ }^{33}$ fókuszálva röviden csokorba szedjük a legfontosabb hazai vonatkozásokat. Gyakorlati tapasztalat, hogy a közérthetőség érdekében célszerű a témát az abban részt vevő szereplők részéről megközelíteni. Az eljárás alanyai a tervező, kivitelező és a hatóság, azonban a tudatosság növelése és a szakszerű végrehajtás teljesítésekor lényeges szerepe van a tűzvédelmi szervezetnek

28 Bécsi Közgazdaságtudományi Egyetem rövidítése (német).

29 www.nachrichten.at/oberoesterreich/Umbauarbeiten-loesten-Brand-im-Linzer-U-Hof-aus-Millionenschaden;art4,192543 (A letöltés dátuma: 2019. 08. 01.); https://apps.derstandard.at/privacywall/story/1324410967608/ oberoesterreich-feuer-auf-baustelle-des-neuen-linzer-musiktheaters (A letöltés dátuma: 2019. 08. 01.); www. vienna.at/vor-10-jahren-brannten-die-sofiensle-ab/2692868 (A letöltés dátuma: 2019. 08. 01.); https://kurier. at/chronik/oesterreich/kitzbuehel-hotel-stand-in-vollbrand/400553093 (A letöltés dátuma: 2019. 08. 15.); www. oe24.at/oesterreich/chronik/wien/Donau-Zentrum-Loesten-Bauarbeiten-Brand-aus/371092213 (A letöltés dátuma: 2019. 08. 01.)

30 Fire statistics monitor 2010; DCLG 2012.

31 9/2015. (III. 25.) BM rendelet; 1996. évi XXXI. törvény.

32 VERZONI 2017; www.modernbuildingalliance.eu/fire-safety-statistics/?_sm_au_=iHV7NV5qj0HDrOms (A letöltés dátuma: 2019. 08. 01.)

33 Itt értsd a 1996. évi XXXI. törvény 4.§ c) pontjában szereplő tűzmegelőzés érvényesítésére irányuló tudatos tevékenységet. 
és tűzvédelmi szakembereknek. A részletes kifejtés előtt érdemes tisztázni az alapelveket és definiálni néhány fogalmat.

Az országos településrendezési és építési követelményekről szóló kormányrendelet (röviden OTÉK ${ }^{34}$ ) a tűzbiztonság fogalma körében elöírja, hogy az építményrészek, önálló rendeltetési egységek, helyiségek alkotóelemeinek megválasztása olyan módon történjen, amellyel az állékonyságot növeli, tűz és füst és a kísérő jelenségek keletkezését, terjedését korlátozza, hogy a mentés és a menekülés biztosított legyen a benntartózkodóknak és a beavatkozó egységek tagjainak. A tervezőnek garantálnia kell ezt a feltételt építési termékek megfelelő megválasztásával, illetve a megfelelő tűzállékonyság biztosításával, különböző müszaki módszerekkel, legyen az passzív vagy aktív eszköz. A tủzbiztonsági alapvetések megtételekor kiindulási feltételnek tekintjük, hogy egyetlen tüz van, illetve az építményt rendeltetés szerint használják. Ennek ellentmondó, valós hiányosságok adódhatnak a kivitelezési munkálatok során. A tervezett tủzszakaszok nem véglegesek, azaz integritásuk nem a kívánt fokon áll, vagy a betervezett védelmek müködésképtelenek. Ezen állapotok általában az egyeztetési jegyzőkönyvnek, illetve az állásfoglalásoknak, engedélyeknek mint a tűzvédelmi dokumentációknak nem részük.

Az építőipari kivitelezési tevékenységről szóló kormányrendelet jogosan beemeli az építtetőt, a beruházót, az építészeti-műszaki tervezőt, a felelős műszaki vezetőt, az építési műszaki ellenőrt, a tervezői művezetőt a felelősségi körbe. A kivitelezési tervdokumentáció tartalmi részletessége segítséget nyújthat naplóvezetéskor, megjelölve a szereplők kötelezettségeit és feladatait. A már lefektetett végleges leírásokban a kivitelezési terveket elkészítő jogosult az elvárt teljesítményadatokat módosítani, ${ }^{35}$ de nem térhet el a jogerős építésügyi hatóság engedélyében jóváhagyottaktól. Fontos tény, hogy ha a kivitelezés és engedélyezés között időbeli elcsúszás van, az eredeti engedélykor megfelelő szabályozás érvényes, ez a munkálatok alatt vagy annak meghosszabbításkor sem módosul.

Az építtetőnek jó tudnia, hogy a szabályozást tekintve, az OTSZ-követelmény és a TVMI ${ }^{36}$ megoldás egymásra épülő kettőse harmonizál az uniós előírások rendszerével is. Egyszerűbben elmondva, a CPR ${ }^{37}$ határozza meg, mely építési termékeket alkalmazzuk, az építési szabvány pedig, hogy mit és hogyan vizsgáljunk, az OTSZ, ${ }^{38}$ hogy mit kell betartani, a TvMI pedig, hogy milyen mértékű megoldást válasszunk. A kivitelezést végzők közül tüzveszélyes tevékenységet csak tűzvédelmi szakvizsgával rendelkező személy gyakorolhat. Beruházásoknál tűzgyújtási engedélyt csak és kizárólag a megbízott és a jogszabályi feltételeknek megfelelő képzettséggel rendelkező tűzvédelmi szakember adhat ki, a tűzgyújtási engedélyben meghatározott feltételekkel. ${ }^{39}$

Szintén tüzvédelmi szakvizsgához kötöttek bizonyos foglalkozási ágak és munkakörök, ezek csak képesítési feltétel teljesülése esetén végezhetők. ${ }^{40}$

34 253/1997. (XII. 20.) Korm. rendelet.

35 Építésitermék-rendelet. Magyar jogrendszerben a 275/2013. (VII. 16.) Korm. rendelet.

36 Túzvédelmi Müszaki Irányelv.

37 Építési Termék Rendelet. Magyar jogrendszerben a 275/2013. (VII. 16.) Korm. rendelet.

38 Országos Tüzvédelmi Szabályzat. Jelenleg hatályos az 54/2014. (XII. 5.) BM rendelet.

39 Több napra is, de legfeljebb 1 hétre szokták kiadni, de ideális, ha csak az adott napra, feladatra, müszakra vonatkozó hatályú. A tűzgyújtási engedély bármikor visszavonható, és szükség esetén újabb tűzgyújtási engedély készithetö.

40 45/2011. (XII. 7.) BM rendelet. 
2015 óta gazdálkodó szervezetek számára tűzvédelmi szakképesítéssel rendelkező személyt kell alkalmazni (megbízni) tárolási, raktározási tevékenység esetén, ha túllépi az előirt $1000 \mathrm{~kg}$ tüz- és robbanásveszélyes mennyiséget vagy a területe több 10 ezer $\mathrm{m}^{2}$-nél, illetve a tömegtartózkodásra szolgáló helyiség befogadóképessége meghaladja az 500 főt, amely létszám függ a menekülési képességtől is, ezért lehet alacsonyabb kötelezettségértéke, így 20 fő felett is érvényesíteni kell. Azonban ilyen javaslat és előírás nincs az építkezésekre vonatkozóan, végzettség nem szükséges a felelős személy számára. Annak ellenére, hogy a tüz elleni védekezésről, a müszaki mentésről és a tűzoltóságról szóló törvény kötelezi a gazdálkodókat szabályzat készítésére. ${ }^{41}$

Az építési munkahelyeken és az építési folyamatok során megvalósítandó minimális munkavédelmi követelményekhez biztonsági és egészségvédelmi koordinátort kell kinevezni, aki természetes személy. Ezenfelül a 4. melléklete tartalmazza az „építési munkahelyeken és az építési folyamatok során megvalósítandó minimális egészségvédelmi és biztonsági követelmények" címszó alatt azt, hogy az „építési munkahely jellegétől, a helyiségek méretétől és használatától, az alkalmazott berendezésektől, felszerelésektől, az ott lévő anyagok fizikai és vegyi tulajdonságaitól, valamint az ott tartózkodó munkavállalók lehetséges legnagyobb létszámától függően, a munkahelyeket megfelelő számú, a tűz oltására alkalmas készülékekkel, illetve külön jogszabályok szerint tűzérzékelő, jelző- és riasztóberendezéssel kell ellátni". 42

Ebben a rendeletben szerepel az első kötelezettség a biztonság megteremtésére, amely nevesíti az építkezés szereplőjét, a BE-koordinátort, ${ }^{43}$ indokolt javaslatait a felelős műszaki vezető a biztonságért viselt felelőssége keretében érvényesíti. A munkáltató köteles a koordinátor javaslatait figyelembe venni. A gyakorlat szerint a tervezői és a kivitelezői feladatokat más-más személy látja el. Ez jól kiforrott rendszer felé mutat, azonban munkavédelmi végzettséggel kell rendelkeznie és a tapasztalat azt mutatja, hogy bejelentésköteles építkezések során jelenik meg általában ez a szerepkör, amikor a tervezett munka mennyisége meghaladja az 500 embernapot, vagy az építőipari kivitelezési tevékenység időtartama előreláthatóan meghaladja a 30 munkanapot és egyidejűleg ott több mint 20 fő munkavállaló végez munkát. ${ }^{44}$

Lényeges, hogy az épületre vonatkozó tűzvédelmi használati szabályok tartalmazzák az üzemeltetési előírásokat, de az épületek tűzvédelmi követelményeknek való megfelelésének dokumentálását viszont tűzvédelmi szakértői vagy tűzvédelmi tervezői jogosultsághoz kötik. De az ideiglenes szerkezetek védelméről nem tesz említést a jogalkotó itt sem. A fentiekben említett tervezői és koordinátori részről feladatként határozza meg, hogy az építészeti-műszaki tervdokumentáció része a tűzvédelmi dokumentáció, és előzetes engedélyeztetéshez köti a beépített tűzjelző-berendezés vagy beépített tűzoltó berendezés létesítését. ${ }^{45}$

\footnotetext{
9/2015. (III. 25.) BM rendelet; 1996. évi XXXI. törvény.

4/2002. (II. 20.) SZCSM-EüM együttes rendelet.

Biztonsági és egészségvédelmi koordinátor.

4 4/2002. (II. 20.) SZCSM-EüM együttes rendelet.

9/2015. (III. 25.) BM rendelet.
} 
Az előbbiekben megfogalmazottakhoz képest változást hozhat a most elfogadott OTSZ-t módosító rendelet, amely szerint passzív tárolás, azaz a bontott csomagolás és a tűzjelző telepítésének megkönnyítése és az átjelzési kötelezettség csökkentése szintén hatással lehet az építkezésekre. ${ }^{46}$

További két szereplőt tudunk kiemelni. Tapasztalat az, hogy az ipari beruházások biztonságtechnikai vonatkozásai kapcsán a mindenkori vagyonőr nem csupán a vagyon elleni cselekmények megakadályozását köteles foganatosítani, hanem a tevékenységéhez szorosan kapcsolódik a tűz jelzése, és tüz esetén az életmentésben való részvétel. Tüzet tapasztalhat a zárt láncú elektronikus megfigyelő rendszeren, szabad szemmel, járőrszolgálat kapcsán vagy a kialakított tűzjelző rendszereken keresztül. Itt fontos megjegyezni, hogy a kialakított tűzjelző rendszer jelzésekor minden esetben önmagának az őrnek is meg kell győződnie a tűz valódiságáról, és szükség esetén pedig értesítenie kell a tűzoltóságot. Távfelügyeletbe bekötött tűzjelző rendszer esetén a téves jelzést is le kell jelentenie a tüzoltóságnak.

Lényeges kiemelni az üzemeltető felelősségét. Az üzemeltető a létesítmény, épület vagy épületrész üzemeltetését ellátó, az üzemeltetés során a tűz elleni védekezésről, a műszaki mentésről és a tűzoltóságról szóló törvényben ${ }^{47}$ meghatározott követelmények biztosításáért felelős. Azonban, ha ez nem egyértelmű, a tulajdonost terheli a felelősség, ezért a szerződésekben részletesen ki kell térni ennek szabályozására. Bár nem tárgya a cikknek, de a Nyugatipályaudvar 2011-es ${ }^{48}$ tüzesete után, ha csak a kiemelt esetekben is, de a rendezvények helyzete fókuszba került és azokat rendezték. ${ }^{49}$

Biztosítóknál már találunk erre kezdeményezést, mint például az Allianz 112. záradékát, amely az építkezés helyszínén alkalmazandó tüzbiztonsági szabályokra vonatkozó feltételekre terjed ki. Itt külön engedélyezési eljárást ír elő a bitumenfelhordásra és a csiszolásra ${ }^{50}$ egyaránt, illetve a tủzcsapszekrények beépítését már a zsaluzás után közvetlenül végre kell hajtani, és az elöírtakat minden munkafázisra alkalmazni kell. ${ }^{51}$

Tűzvédelmet a biztonsági és egészségvédelmi koordinátor számos tevékenysége mellé olvasztotta be, nem specifikálva azt, ezért elvesztette a terület a hangsúlyát. ${ }^{52} \mathrm{~A}$ szakmának vannak más értékes segédanyagai, mint a hazai burkolóknak és BE-koordinátoroknak. A Magyar Építőkémia és Vakolatszövetség (MÉSZ) a Kivitelezési irányelvében számtalan példát felsorol a helyes rétegrend megalkotására és javítására. Sajnálatos azonban, hogy a gyakorlatban csak kevés helyen használt vagy ismert irodalom (10. ábra). ${ }^{53}$

46 30/2019. (VII. 26.) BM rendelet.

47 1996. évi XXXI. törvény 18. §.

48 West Balkán szórakozóhelyen történt tüzeset során három lány életét vesztette. https://index.hu/bulvar/2011/01/16/ harom_lanyt_megoltek_a_west_balkanban/ (A letöltés dátuma: 2019. 08. 01.)

49 „(1) A rendezvény szervezőjének irányítási pontot kell létrehozni, ahol legalább a rendezvény szervezője, a rendezvény biztonsági vezetője, a rendezvény tűzvédelmi felelőse és esetleges káreset során a rendőrség, a mentők, valamint a katasztrófavédelem intézkedésre jogosult képviselői végeznek irányítói feladatokat. (2) Az irányítási ponton keresztül a rendezvény szervezője biztosítja a kommunikációs és tömegtájékoztatási lehetőséget." 54/2014. (XII. 5.) BM rendelet 217. §.

50 Még polírozásra is.

51 112. záradék 2003.

52 Lásd az OMMF útmutatóját. HARMAT-SOMOGYI 2012.

53 MÉSZ, Kivitelezési Irányelv 2014. 

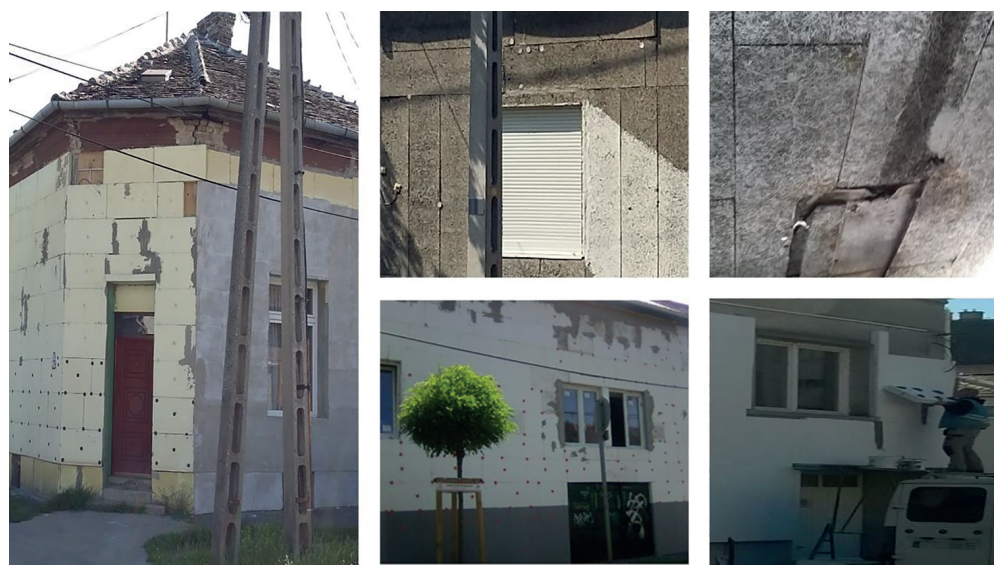

10. ábra. Képek az épületek szigetelés-korszerüsítési munkálatainak hibáiról

Forrás: a szerzők felvételei

Fontos megemlíteni, hogy a Honvédségre az 1996. évi XXI. törvény 23. § (3) bekezdése nem terjed ki, hanem a 15/2017. (X. 20.) HM rendelet értelmében példaértékü ágazati szabályozás is megvalósulhat.

\section{Külföldi példák}

A hazai szabályozás után tegyünk kitekintést külföldi példákra. Kezdjük a kanadai gyakorlattal, amelyről valószínüleg elmondható, hogy az építkezési szokásokból ${ }^{54}$ és brit-angol jogalkotási módszerből és hagyományból ered. Az építkezésekre vonatkozó szabályok helyi szintűek és területenként különbözőek, de áthidaló megoldásként például a Kanadai Fa Tanács $(\mathrm{CWC})^{55}$ külön útmutatót dolgozott ki a témában. Ontario Állam saját segédletet adott közre, hogy megfelelő gyakorlatot alakítson ki öt- és hatemeletes faszerkezetű épületekre. ${ }^{56}$

Svájcban szövetségi szinten van megemlítve az építési szabályzat (rendelet) (BauAv). Már 2006-ban elfogadta az átdolgozást a Szövetségi Tanács. Előírja, hogy az épületeknél és létesítményeken végzett munkák során az összes érintett félnek megfelelő intézkedéseket kell hoznia annak érdekében, hogy hatékonyan ellensúlyozza az építési folyamat okozta megnövekedett tüz- és robbanásveszélyt. ${ }^{57}$

54 Itt értsd a fát, amely, ha minden elem a helyén van és kész az épület ugyanolyan biztonságos, mint a vas- vagy betonszerkezet, de a kivitelezés során, a védelmek megléte előtt sérülékeny.

55 Canadian Wood Council.

56 Fire Safety Ontario 2016.

57 Bauarbeitenverordnung (BauAV) 2005. 
Ausztriában a tűzvédelem általános szempontjából, de különösen a forró munka során is, a Bundesfeuerwehrverband ÖBFV közzéteszi az úgynevezett „TRVB-ket” (a megelőző tűzvédelem műszaki irányelveit). Építkezési területeken a TRVB 149 85-öt már régóta használták. Jelenleg hatályon kívül van, és 2017 tavaszától kezdve a TRVB 104 O a használatos, amely számos rendeletet tartalmaz az építkezésen végzett forró munkákról. Ezenkívül a vonatkozó iparág dokumentumaira és a telepítési utasításokra hivatkozások a mértékadók a témában. A szerzők szerint azonban a TRVB 104 O nem elégséges alap az építkezés konkrét helyzeteire, mivel nem egyértelmü. ${ }^{58}$

Az Amerikai Egyesült Államokban a Nemzeti Tüzvédelmi Szövetség által kiadott szabványt használják. Kidolgozott minimumkövetelmény-rendszer van az építkezés, átalakítás, bontás tűzvédelmére, amelyet az NFPA 241-ben foglaltak össze, amely már közel 80 éves. Utolsó frissítés 2018-ban volt.

Ahol az amerikai és nemzetközi tüz-, illetve épületkód, valamint a NFPA 1 szabvány érvényben van, abban az államban az NFPA 241 betartása kötelező érvényü. Kiterjed az időszakos építésre, épületre, eszközökre és tárolásra, folyamatokra, illetve veszélyekre. Egyik lényegi pillére a műszaki előírásnak a tűzvédelmiprogram-menedzser (FPPM) ${ }^{59}$ vagy a helyettese, aki projektszinten hangolja össze és minden tüzbiztonságot érintő feladatot koordinál. Másik a programterv, amelyet folyamatosan követni kell és mindig aktualizálni. ${ }^{60}$

Az utóbbi követelmény nálunk is terjedőben van. Tapasztalatunk szerint egyre elterjedtebb a hazai amerikai vállalatoknál a tüzőr fogalma. ${ }^{61}$ Nem lehet más feladata az alkalmi tűzveszélyes munka végzésekor, mint a folyamatos kontroll. A forró munka teljes időtartama alatt folyamatos felügyeletet kell fenntartani, ideértve a forró munka befejezése után egy 30 perces lehütési periódust is. Bár tapasztaltuk, hazai vegyipari vállalatnál ezt az időt a vezetőség - igaz, belső döntés alapján - 60 percre növelte. Másik meghonosodó elv a veszélyes tényező kizárása, amely számos esetben jelent müszaki gátat, még hibázás esetén is. ${ }^{62}$

\section{Következtetések}

A hírekből jól ismertek a témával kapcsolatos történetek. Lenyügöző képek, de jelentős károk és nem kívánt médiaérintettség, és nem utolsósorban építési késések és többletköltségek jellemzik őket. Az építkezés alatt bekövetkező tűz súlyos esemény. Idehaza sajnos, az álláspontunk szerint az építkezésen a tűzvédelem fontosságát érdemtelenül alábecsülik, ha a koncepciók kidolgozottak ${ }^{63}$ is. A legtöbb esetben a „tervezés” részét nagyon jól hajtják végre. Gyakran azonban a projekt előrehaladását érintő változások esetében vagy bizonyos kivitelezési típusoknál és fegyelmet hanyagoló vállalatoknál az elvárt biztonsági szint sérül.

8 ÖBVF TRVB 149/85 (A) 1985.

59 Fire Protection Program Manager.

60 www.nfpa.org/constructionfires (A letöltés dátuma: 2019. 08. 01.)

61 Itt fire watch.

62 OSHAS 1910.252.

63 Eurocode, úgymond harmonizált minőségbiztosítási követelményrendszer (szabványok). 
A változtatáshoz a hazai viszonylatokat figyelembe vevő környezetet kell teremteni úgy, hogy ha a veszélyek vagy ha az építkezés mérete ezt megköveteli, a munka időtartamára „tűzvédelmi megbízottat"64 kell kinevezni, aki garantálja az építkezésen alkalmazott tűzvédelmi intézkedések végrehajtását. Mindezt természetesen keretek közé szorítva, például egy bizonyos építkezés- és/vagy beruházástípushoz és időtartamhoz kötve, amely kötelezne minden kivitelezőt. Bevezetése annak mértékétől függetlenül valószínüleg elrettentő hatású lenne, és a „biztonsági kultúra" növelő gondosság megteremtését szolgálná. Fontosnak tartjuk leszögezni, hogy célszerü a hatályát kiterjeszteni az átalakítási, felújítási, renoválási és nem utolsósorban karbantartási munkálatokra is. Továbbá elörelátásunk szerint a szankciók és az ellenőrzés, illetve a Mérnöki Kamara iránymutatása, biztonsági és egészségkoordinátorok tevékenységének jogosultsághoz való kötése, továbbképzési kötelezettsége esetleg növelné a hatékonyságot. Érdemes köztudatba emelni non-profit módon működő társaságokat, amelyek oktatási mủhelyeket hívnak össze és megvitatják az egyes eljárásokat. A tűzveszélyes tevékenységet engedélyezőktől a kötelező ismeret frissen tartása vagy „tűzőr” rendszer bevezetése elősegítené az építkezéseken elvárt „kultúra” meghonosodását.

\section{Összegzés}

A gazdaságosság gyakran nagyobb szerepet játszik a műszaki döntésekben, ezért jelenleg a tűzbiztonság kérdése ritkán kerül az őt megillető helyére az építési prekoncepcióknál. A tűzvédelmi kérdésekkel foglalkozó felelősnek a biztonság növeléséhez hozzá kell járulnia és a kivitelezési tervezésbe, az ütemezésekbe és biztonsági részek kialakításába is be kell vonni, amelynek hiánya sokszor érezhető. Külföldön, részben az építési szokásoknak köszönhetően, létezik élő példa és praktika a kockázatok kezelésére, ezért különösen öröm, hogy idehaza is találkozhatunk ilyen önkéntes kezdeményezéssel az építkezéseken, ahol a tűzbiztonsági kultúrát eredményesen honosították meg.

Bízunk benne, hogy sikerült felhívni a figyelmet a terület fontosságára és sürgető szabályozására. Igyekeztünk a cikkünkkel a témában iránymutatásként szolgálni az érdeklődőknek, és az önszerveződésben bízva reméljük, hogy az elkövetkezőkben a problémát hasonlóan észlelők körében megfelelő fórum és konstruktív javaslatok látnak napvilágot az építési munkahelyek tűzvédelemének terén, amely hasznosítható a honvédségi szakág számára egyaránt. Legyen ez akár csak egy ágazati kezdeményezés.

64 Legyen akár a személye a jogszabály szerint már ismert szereplőkhöz is kötve. 


\section{Felhasznált irodalom}

Brushlinsky, Nikolai - Ahrens, Marty - Sokolov, Sergei V. - WAgner, Peter (2019): World Fire Statistics No. 24. Center of Fire Statistics of CTIF. Elérhető: www.ctif.org/sites/default/files/news_files/2019-04/CTIF_Report24_ERG.pdf (A letöltés dátuma: 2019. 08. 01.)

BRUSHLINSKY, Nikolai - AHRENS, Marty - WAGNER, Peter - BÉRCZI, László (2018): World Fire Statistics No. 23. CTIF, 2018. Elérhető: www.ctif.org/sites/default/files/2019-06/CTIF_Report23-Hungarian_191102\%20\%281\%29.pdf (A letöltés dátuma: 2019. 08. 01.)

DCLG (2012): Analysis of fires in buildings of timber framed construction, England, 2009-10 to 201112. London, Department for Communities and Local Government.

Fire Safety During Construction for Five and Six Storey Wood Buildings in Ontario (2016). Ontario, Ministry of Municipal Affairs and Housing.

Fire statistics monitor (2010). Department for Communities and Local Government, London April 2009 to March 2010, London, London Communities and Local Government Publications.

Harmat Anna - SOMOGY Gyula (2012): Módszertani útmutató biztonsági és egészségvédelmi koordinátorok részére. Budapest, BÉTÉ Szervező és Szolgáltató Bt.

JÁMBOR Attila - Koós Miklós (2015): Azt építünk, amit akarunk? Nem számít a HÉSZ? Elérhető: https:// epitesijog.hu/1843-azt-epitnk-amit-akarunk-nem-szamit-a-hesz (A letöltés dátuma: 2019. 08. 01.)

JÁMBOR Attila (2019): Júliusi és szeptemberi változások az egyszerü bejelentés előírásaiban. Elérhető: https://epitesijog.hu/8728-juliusi-es-szeptemberi-valtozasok-az-egyszeru-bejelentes-eloirasaiban (A letöltés dátuma: 2019. 08. 31.)

JuHÁsz D. Géza (2015): A halasi tüzoltók is oltottak Majsán - Képek. Elérhető: http://halasinfo.hu/ahalasi-tuzoltok-is-oltottak-majsan-kepek/ (A letöltés dátuma: 2019. 08. 01.)

KÁLMÁNFI G. (2007): Modern honvédkórház - nem csak katonáknak. Elérhető: http://epulettar.hu/cikk/ modern-honvedkorhaz-nem-csak-katonaknak (A letöltés dátuma: 2019. 08. 01.)

Kıss András (2015): Szeptemberre eldöl a Kodály köröndiek sorsa. Elérhetö: www.origo.hu/itthon /20150715-beperelik-biztositot-leegett-kodaly-korondi-haz-lakoi.html (A letöltés dátuma: 2019. 08. 01.)

Koós Miklós (2016): 456/2015. (XII. 29.) Korm. rendelet | Megerőszakolták az építési törvényt. Elérhető: http://koos.hu/2016/01/02/456-2015-xii-29-korm-rendelet-megeroszakoltak-az-epitesi-torvenyt/ (A letöltés dátuma: 2019. 08. 01.)

MÉSZ, Kivitelezési Irányelv (2014). Betonréteggel ellátott, többrétegű ragasztott táblás homlokzati hőszigetelő rendszerek (ETICS-THR) kivitelezése. Budapest, Magyar Építőkémia és Vakolat Szövetség (MÉSZ).

MTI (2014a). NSZ: Csak homokkal próbálták megelőzni a munkások az Andrássy úti tüzet. Elérhető: https://hvg.hu/itthon/20140730_NSZ_Csak_homokkal_probaltak_megelozni_a_m (A letöltés dátuma: 2019. 08. 01.)

MTI (2014b): Leégett egy Andrássy úti ház teteje. Elérhető: www.origo.hu/itthon/20140715-eg-egyandrassy-uti-haz-teteje.html (A letöltés dátuma: 2019. 08. 01.)

MTI (2015): Tüz ütött ki Hévízen! Csaknem ötven embernek kellett elhagynia az otthonát. Elérhetö: https:// alfahir.hu/tuz_utott_ki_hevizen_csaknem_otven_embernek_kellett_elhagynia_az_otthonat (A letöltés dátuma: 2016. 02. 01.)

NFPA Research (2017): Fires in structures under construction, undergoing major renovation or being demolished, fact sheet 617.984.7450. NFPA Research, Data \& Analytics - REV. Elérhető: www.nfpa. org/-/media/Files/News-and-Research/Fire-statistics-and-reports/Fact-sheets/FiresInStructuresUnderConstructionFactSheet.pdf (A letöltés dátuma: 2019. 08. 01.)

OSHAS 1910.252 General requirements. Welding, Cutting, and Brazing. Occupational Safety and Health Administration.

PAP Melinda (2008): Keresik a felelösöket a tüzvész ügyében. Elérhető: https://kronikaonline.ro/erdelyihirek/keresik_a_felelosoket_a_tuzvesz_ugyeben (A letöltés dátuma: 2019. 08. 01.) 
R. BAKONYI Ágnes (2004) MP - orvosok. Duna TV felvétele, Nemzeti Audiovizuális Archívum, Elérhető: http://nava.hu/id/00742_2004/ (A letöltés dátuma: 2019. 08. 01.)

Reuters (2016) Paris Ritz: Fire under control at world-famous hotel. Elérhetö: www.bbc.com/news/worldeurope-35351013 (A letöltés dátuma: 2019. 08. 01.)

Reuters (2019): Hatalmas tüz a párizsi Notre-Dame-ban. Elérhető: https://hu.euronews.com/2019/04/15/ kigyulladt-a-notre-dame-szekesegyhaz-parizsban (A letöltés dátuma: 2019. 08. 01.)

SzABÓ Fruzsina (2015): A szakértő szerint a katasztrófavédelem csupán vallomások alapján állapitotta meg a Kodály köröndi tüz okát. Elérhető: https://pestisracok.hu/szakerto-szerint-katasztrofavedelem-csupan-vallomasok-alapjan-allapitotta-meg-kodaly-korondi-tuz-okat/ (A letöltés dátuma: 2019. 08. 01.)

SZATMÁRI Zoltán (2008): Mamut az egészségügyben. Médiatár (Centrál Digitális Média Kft.). Elérhető: www.50plusz.hu/mediatar/media/Mamut_az_egeszsegugyben/2123 (A letöltés dátuma: 2019. 08. 01.)

TAKÁCs Lajos Gábor (2012): A kivitelezés gyakorlati tüzvédelmi problémái. Elérhető: www.vedelem.hu/ files/UserFiles/File/konf2012/lakitelek/Dr._Takacs_Az_epiteszeti_kivitelezes_gyakorlati_tuzvedelmi_problemai.pdf (A letöltés dátuma: 2020. 05. 10.)

TARPATAKI Károly (2018): A rönkház tervezése, alapozása és épitése. Elérhető: www.homeinfo.hu/epitkezes-felujitas/tervezes/2313-a-ronkhaz-tervezese-alapozasa-es-epitese (A letöltés dátuma: 2019. 08. 01.)

VERZONI, Angelo (2017): Danger: Construction. NFPA. Elérhető: https://www.nfpa.org/News-and-Research/Publications-and-media/NFPA-Journal/2017/September-October-2017/Features/NFPA241 (A letöltés dátuma: 2019. 08. 01.)

\section{Jogi források}

1996. évi XXXI. törvény a tủz elleni védekezésröl, a müszaki mentésről és a tűzoltóságról

253/1997. (XII. 20.) Korm. rendelet az országos településrendezési és építési követelményekröl

275/2013. (VII. 16.) Korm. rendelet az építési termék építménybe történő betervezésének és beépítésének, ennek során a teljesítmény igazolásának részletes szabályairól

45/2011. (XII. 7.) BM rendelet a tűzvédelmi szakvizsgára kötelezett foglalkozási ágakról, munkakörökröl, a tủzvédelmi szakvizsgával összefüggő oktatásszervezésröl és a tűzvédelmi szakvizsga részletes szabályairól

54/2014. (XII. 5.) BM rendelet az Országos Tüzvédelmi Szabályzatról

9/2015. (III. 25.) BM rendelet a hivatásos katasztrófavédelmi szerveknél, az önkormányzati és létesítményi tủzoltóságoknál, az önkéntes tủzoltó egyesületeknél, valamint az ez irányú szakágazatokban foglalkoztatottak szakmai képesítési követelményeiről és szakmai képzéseiről

30/2019. (VII. 26.) BM rendelet az Országos Tűzvédelmi Szabályzatról szóló 54/2014. (XII. 5.) BM rendelet módosításáról

4/2002. (II. 20.) SZCSM-EüM együttes rendelet az építési munkahelyeken és az építési folyamatok során megvalósítandó minimális munkavédelmi követelményekröl

ÖBVF, „TRVB 149/85 (Brandschutz auf Baustellen)," Elérhető: www.bundesfeuerwehrverband.at/produkt/trvb-149-85-a-brandschutz-auf-baustellen/ (A letöltés dátuma: 2017. 01. 12.) 


\section{Internetes források}

112. Záradék: A tüzvédelmi berendezésekre és az épitkezés helyszínén alkalmazandó tüzbiztonsági szabályokra vonatkozó különfeltételek (2003). Allianz Hungaria. Elérhető: www.hungarorisk.hu/index. php? $=$ downloads\&parent $=294 \&$ did=294 (A letöltés dátuma: 2019 . 08. 01.)

Andrássy úti tüz: eztállapitotta meg a tüzvizsgálat (2015). Elérhetö: http://magyartarsashaz.hu/2015/01/18/ andrassy-uti-tuz-ezt-allapitotta-meg-a-tuzvizsgalat/ (A letöltés dátuma: 2019. 08. 01.)

Bauarbeitenverordnung (BauAV) (2005). Der Bundesrat, Elérhetö: www.admin.ch/opc/de/official-compilation/2005/4289.pdf (A letöltés dátuma: 2019. 08. 01.)

Baustellenbrand: Großeinsatz auf neuem WU-Gelände (2012). Elérhető: www.derstandard.at/story/1336563133024/baustellenbrand-grosseinsatz-auf-neuem-wu-gelaende (A letöltés dátuma: 2019. 08. 01.)

Besztercén újra szólnak a harangok (2010). Erdély Ma, Elérhetö: http://erdely.ma/kisregio.php?id=58413\&cim=besztercen_ujra_szolnak_a_harangok\&autoid=56883\&year $=2010 \&$ month $=11 \&$ day $=02 \&$ what=archivum (A letöltés dátuma: 2019. 08. 01.)

Donau Zentrum: Lösten Bauarbeiten Brand aus? (2019). Elérhető: www.oe24.at/oesterreich/chronik/wien/ Donau-Zentrum-Loesten-Bauarbeiten-Brand-aus/371092213 (A letöltés dátuma: 2019. 08. 01.)

Feuer auf Baustelle des neuen Linzer Musiktheaters (2011). [Panorama Topic 21. Dezember], Der Standard. Elérhető: www.derstandard.at/story/1324410967608/oberoesterreich-feuer-auf-baustelle-desneuen-linzer-musiktheaters (A letöltés dátuma: 2019. 08. 01.)

Fires in Structures Under Construction, Undergoing Major Renovation, or Being Demolished (2017). NFPA. Elérhető: www.nfpa.org/constructionfires (A letöltés dátuma: 2019. 08. 01.)

Fire Safety Statistics. Modern Building Alliance. Elérhetö: www.modernbuildingalliance.eu/fire-safetystatistics/?_sm_au_=iHV7NV5qj0HDrOms (A letöltés dátuma: 2019. 08. 01.)

Gázrobbanás a darányi óvodában: két súlyos sérült (2013). Elérhető: https://sonline.hu/somogy/kekhirek-bulvar-somogy/gazrobbanas-a-daranyi-ovodaban-ket-sulyos-serult-527187/ (A letöltés dátuma: 2019. 08. 01.)

Három lány meghalt a West Balkánban (2011). Elérhető: https://index.hu/bulvar/2011/01/16/harom_lanyt_megoltek_a_west_balkanban/ (A letöltés dátuma: 2019. 08. 01.)

Húsz év huzavona után fejeződik be a Honvédkórház új szárnyának építése (2002). Elérhető: www.origo. hu/itthon/20011124husz.html (A letöltés dátuma: 2019. 08. 01.)

Kitzbühel: Hotel stand in Vollbrand (2019). Elérhető: https://kurier.at/chronik/oesterreich/kitzbuehelhotel-stand-in-vollbrand/400553093 (A letöltés dátuma: 2019. 08. 15.)

Nyolc év alatt negyvenmilliárdot fizettek ki a biztositók tüzkárokra (2019). Magyar Biztosítók Szövetsége. Elérhető: https://mabisz.hu/nyolc-ev-alatt-negyvenmilliardot-fizettek-ki-a-biztositok-tuzkarokra/ (A letöltés dátuma: 2019. 08. 01.)

A szellözörendszer szigetelése kapott lángra (2015). Elérhető: https://jozsefvaros.hu/hir/2804/a-szellozorendszer-szigetelese-kapott-langra (A letöltés dátuma: 2019. 08. 01.)

Tüz a Margit hídon (2010). Elérhető: https://rtl.hu/rtlklub/hirek/belfold/cikkek/2010/08/29/tuz_a_margit_hidon (A letöltés dátuma: 2019. 08. 01.)

Tüzesetek száma és helye Magyarországon 2006-2016-ig (2018). Lánglovagok Tűzvédelmi Tudásbázis [Forrása a KSH], Elérhető: www.langlovagok.hu/361/tuzesetek-szama-es-helye-magyarorszagon2006-2016-ig/ (A letöltés dátuma: 2019. 08. 01.)

Umbauarbeiten lösten Brand im Linzer U-Hof aus: Millionenschaden (2009). Elérhető: www.nachrichten.at/oberoesterreich/Umbauarbeiten-loesten-Brand-im-Linzer-U-Hof-aus-Millionenschaden;art4,19254 (A letöltés dátuma: 2019. 08. 01.)

Vor 10 Jahren brannten die Sofiensäle ab (2011). Elérhető: www.vienna.at/vor-10-jahren-brannten-diesofiensle-ab/2692868 (A letöltés dátuma: 2019. 08. 01.) 